\title{
Wild Golden Iris (Iris aurantica) in Syria
}

\author{
Khalil AL Maarri*, Thuraya Abou zedan and Nabil AL Batal \\ Faculty of Agriculture, Damascus University, Syria
}

Submission: February 14, 2017; Published: February 27, 2017

"Corresponding author: Khalil AL Maarri, Damascus University, Faculty of Agriculture, Damascus, Syria, Email: kmaarri@yahoo.com

\section{Abstract}

Iris aurantica is a rhizomatous perennial, from the south mountain of Syria (JabalAl Drouze), it has a compact rhizome and falcate leaves. It has a slender stem with flowers golden yellow to coppery-brown. The golden iris in Syria is becoming rare due to destruction of their natural habit. In this paper, plant classification, botanical description, morphological, geographical, chemical composition, in vitro propagation and conservation, and cryopreservation of Iris aurantica are investigated.

Keywords: Morphological; Botanical description; Micro propagation; Conservation; Chemical composition

Abbreviations: MS: Murashige and Skoog; HF-MS: Hormon Free Murashige and Skoog; PVS2: Plant Vitrification Solution 2; LN: Liquid Nitrogen

\section{Introduction}

Syrian flora has 3247 species [1]. There are many of endemic species, some of which belong to genus Lilium, Crocus, Tulips and Iris. Iris is the largest and most complicated genus of iridaceae, which includes over 300 species [2]. This includes some of the world most popular and varied garden flowers that are originated in both Japan and the Mediterranean [3].

In Syria, Iris is considered as a wild perennial herbaceous plant that subjected to strict protection, though Iris grows naturally in many regions of Syria. It presents some 30 species grown in Syria [1]. There are five subgenus found in the world. Apogon, Pogonias, Xiphion, Guno and oncocyclus which includes most of the Syrian species, that are considered as rare endemic plants, characterized by special, beautiful forms that have a great importance in applied studies for genetic biodiversity, such as Iris aurantiaca Dinsm.

Iris aurantica, of Syria was first discovered by Dinsmor on the Tell Quleib in Syria. Mouterde found it in several other places in Djebel Druze, Tell Qouleib, Kafer, Tell Jaffna, Mayamas, Sahwet-El-Khodr [1] and Distribution in the Djebel Druze at about 1600m [4]. Dr. Werkmeister, Professor of Botany at the Botanical Institute, Geisenheim am Rhein, Germany which had the opportunity to collecting the golden Iris in 1961,and cultured it in his garden. The golden Iris flowered in Europe in June one month later than in their natural habit in Syria [5].

Iris plants in Syria are becoming rare due to both ongoing destruction of their natural habit, as well as over harvesting of wild species and the influencing of modernization, i.e., urbanization, migration, determental climatic and environmental changes, adding the huge destruction of plant biodiversity by the hard war since 5 years [6].

In this paper, Plant classification, botanical description, morphological, geographical, chemical composition, genetic variability, in vitro propagation and conservation, and cryopreservation of Iris aurantica were investigated.

\section{Scientific Classification}

Iris aurantica $\mathrm{L}$ is one of the important species that belongs to the family Iridaceae, endemic to Jabal Al `Arab, rhizomatous (with thick, creeping underground stems) [7].
A. Kingdom: Plantae.
B. Unranked: Angiosperm, Monocots. Order Asparagales.
C. Family: Iridaceae. Subfamily: Iridoideae, Tribe: irideae.
D. Genus: Iris, Subgenus: Oncocyclus. Species: Iris aurantica.

\section{Description of Iris aurantica}

Iris aurantica is a perennial plant, growing from compact rhizome that reaches up to $10-14 \mathrm{~cm}$ long. Rhizome develops from axillary buds, it allows new shoots to grow upwards. The golden iris rhizomes planted underground about $5-10 \mathrm{~cm}$ in rocky soils (Figure 1). It uses rhizomes to store nutrients like proteins, starches and lipids, these nutrients become useful for the plant when new shoots will be formed in early spring. 


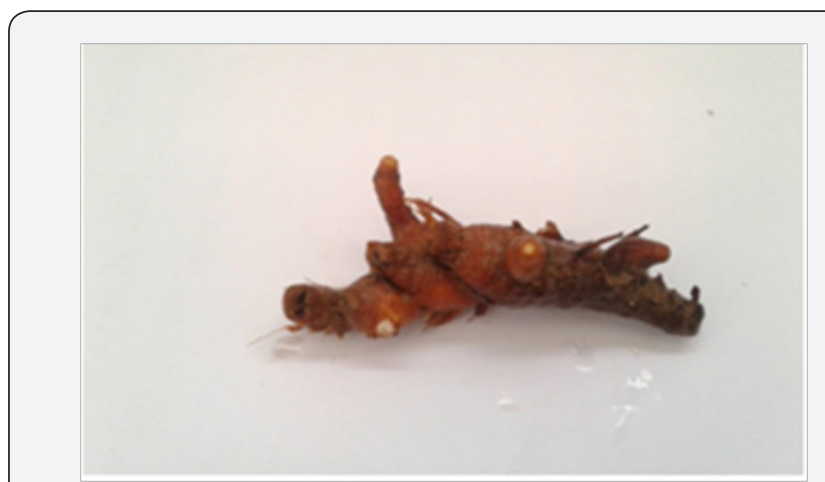

Figure 1: Rhizome of iris aurantica.

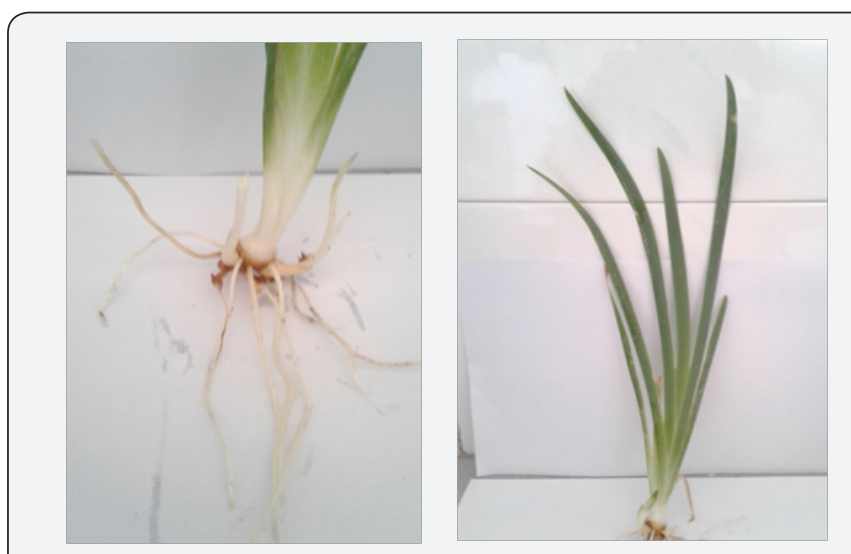

Figure 2: Leaves and roots of iris aurantica.

Iris aurantica has green falcate leaves, they can grow up to $15-25 \mathrm{~cm}$ long and between $1-1.5 \mathrm{~cm}$ wide (Figure 2). Leaves can sheath up to haft of the stem after the iris has bloomed. At the summer sun with dry conditions, leaves fade and die. Golden Iris has a slender stem, which can grow up to $30-50 \mathrm{~cm}$ tall. The stems hold terminal flowers (top of stem), blooming during May and Jun, they can flower for up of month long [4].

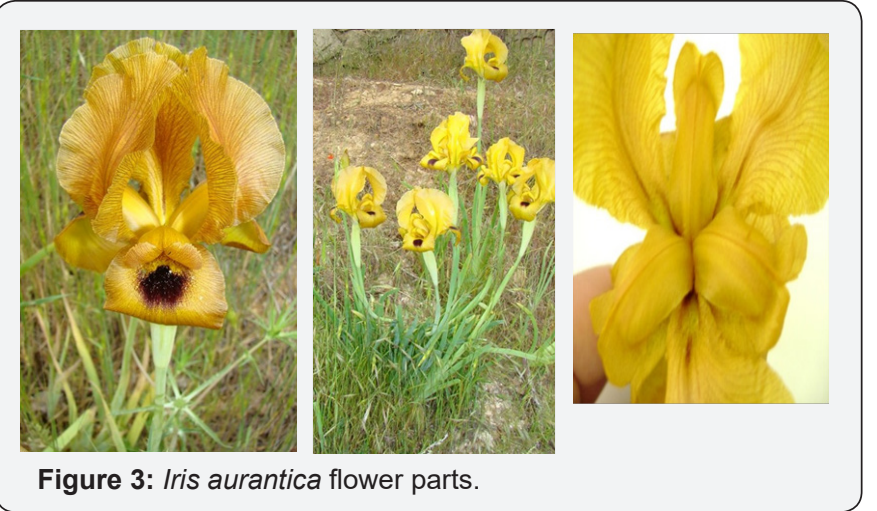

Golden Iris has a slender stem, which can grow up to 30$50 \mathrm{~cm}$ tall. The stems hold terminal flowers (top of stem), blooming during May and Jun, they can flower for up of month long [4]. The flowers like other irises, it has two pairs of petals, three large sepals, known as the falls and three inner smaller petals or sepals, known as the standards. The standards are golden yellow to coppery-brown, 8-9cm long, 5-5.5 wide, with fine purple veins. The falls are oblong-shaped, $7 \mathrm{~cm}$ long, and $4 \mathrm{~cm}$ wide, abovate, with minute purplish red spots and very fine reddish veins. It has golden yellow with fine purple. Style branches (stigma) keeled, and have lobes tips that are a similar color like falls (Figure 3). After the iris has flowered, it produces a seed capsule, $8 \mathrm{~cm}$ long, rather narrow.

The golden iris flowered in Europe in June, a whole month later than in their habitat in Syria. The unexpectedly cold European weather in the spring of 1962 had nearly everywhere in Europe killed the flowers on the iris species. The only exception and a unique consolation, was the plants of Iris aurantica from Syria, which gave us much joy with their flowers [5].

\section{Golden Iris Propagation}

The propagation of Iris species is usually accomplished vegetatively through bulbs or splitting of rhizomes (rhizomatous Iris). In rhizomatous Iris, splitting the rhizomes gives a maximum of 10 plants per year per rhizome [8]. Furthermore, the propagation of Iris species through seedlings is known to be difficult due to a poor fruit set and a very low germination rate.

Plant tissue culture is a powerful alternative technique for propagation and conservation of plants, especially for those that are rare and difficult to propagate by conventional methods. Therefore, a new trend has evolved to propagate these species through tissue culture techniquein order to preserve it from deterioration and to study the possibility of using them as a medical or ornamental plant.

Micro propagation is the aseptic culture of cells, pieces of tissue, or organs. It is possible to regenerate new plants from small pieces of plant tissue identical to the plant from which it was derived.

The process of micro propagation can be divided into four stages:

A. Initiation stage: The objective of this stage is to achieve an aseptic culture. An aseptic culture is one without contaminating bacteria or fungi. Base of leaves and shoot tips of rhizomes in Iris aurantica (after surface disinfection by chlorox $3 \%$ ) were cultured on solidified MS medium containing $30 \mathrm{~g} / \mathrm{l}$ sucrose, and supplemented with $2 \mathrm{mg} / \mathrm{lBAP}$ and $0.2 \mathrm{mg} /$ IIBA (Abouzedan and Al-Batal 2015). Results showed, after one month of culture, that using shoot tips of rhizomes resulted in the highest growth percentage (35.76\%) in initial stage [9].

B. Multiplication stage: A growing ex plant can be induced to produce vegetative shoots by including a cytokinin in the medium and different media. In Iris aurantica, the highest average number of shoots per ex plant was found (3.43) under BAP at a concentration of $3.0 \mathrm{mg} / \mathrm{l}$ (Figure 4), and MS media resulted in the highest multiplication rate and shoot length with significant difference compared with Heller media, Subculture of the plantlets on the same medium resulted in increasing multiplication rate and shoot length in Iris aurantica [9] the 
treatment of high concentrations of cytokinins (5 and 10mg/ IBAP) consist of appearance of vitrification.

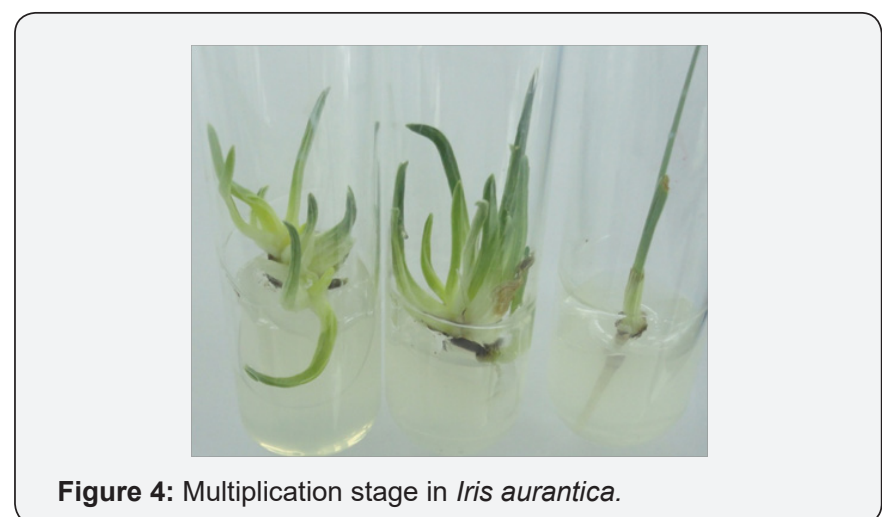

C. Rooting stage: Growing shoots can be induced to produce adventitious roots by including an auxin in the medium. In iris aurantica, the highest root percentage (88.5\%) was obtained on medium containing $3 \mathrm{mg} / \mathrm{lIBA}$ (Figure 5). The highest root number (4.25) was recorded when using the concentration $0.5 \mathrm{mg} /$ lIBA [9] (Table 1).

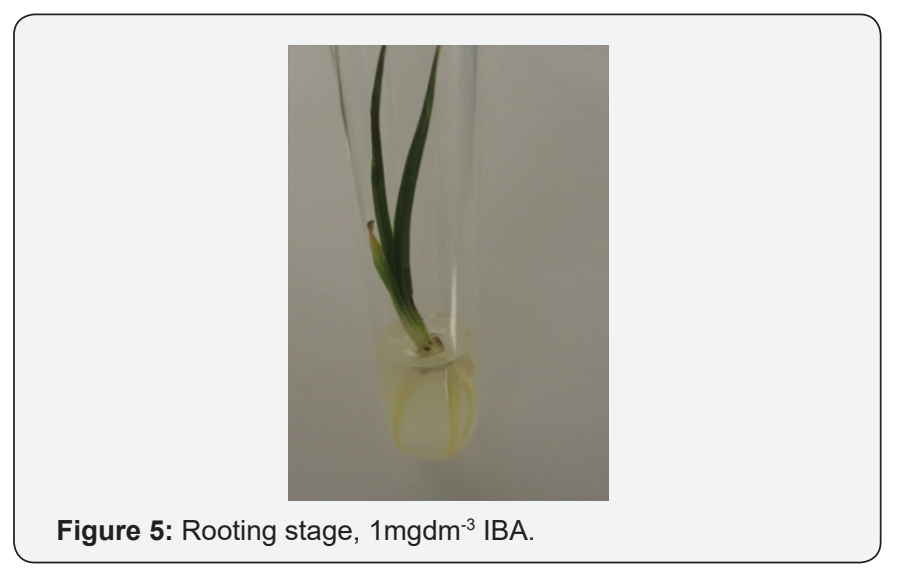

Table 1: The best media of tissue culture in iris aurantica.

\begin{tabular}{|c|c|c|c|}
\hline $\begin{array}{l}\text { Compositions of } \\
\text { Growth Medium }\end{array}$ & $\begin{array}{l}\text { Initiation } \\
\text { Stage }\end{array}$ & $\begin{array}{l}\text { Multiplication } \\
\text { Stage }\end{array}$ & $\begin{array}{l}\text { Rooting } \\
\text { Stage }\end{array}$ \\
\hline Medium & MS & MS & $1 / 2 \mathrm{MS}$ \\
\hline Sucrose & $30 \mathrm{~g} \mathrm{dm}^{-3}$ & $30 \mathrm{~g} \mathrm{dm}^{-3}$ & $30 \mathrm{~g} \mathrm{dm}^{-3}$ \\
\hline Agar & $7 \mathrm{~g} \mathrm{dm}^{-3}$ & $7 \mathrm{~g} \mathrm{dm}^{-3}$ & $7 \mathrm{~g} \mathrm{dm}^{-3}$ \\
\hline $\begin{array}{l}\text { Thiamine(vitamin } \\
\text { B1) }\end{array}$ & $1 \mathrm{mg} \mathrm{dm}^{-3}$ & $1 \mathrm{mg} \mathrm{dm}^{-3}$ & $1 \mathrm{mg} \mathrm{dm}^{-3}$ \\
\hline Myo- inositol (B8) & $100 \mathrm{mg} \mathrm{dm}^{-3}$ & $100 \mathrm{mg} \mathrm{dm}^{-3}$ & $100 \mathrm{mg} \mathrm{dm}^{-31}$ \\
\hline \multicolumn{4}{|c|}{ Hormones } \\
\hline BAP & $2 \mathrm{mg} \mathrm{dm}^{-3}$ & $3.0 \mathrm{mg} \mathrm{dm}^{-3}$ & 0 \\
\hline IBA & $0.2 \mathrm{mg} \mathrm{dm}^{-3}$ & $0.1 \mathrm{mg} \mathrm{dm}^{-3}$ & $3.0 \mathrm{mg} \mathrm{dm}^{-3}$ \\
\hline \multicolumn{4}{|c|}{ Other Compounds } \\
\hline Activated Carbon & $3 \mathrm{~g} \mathrm{dm}^{-3}$ & - & - \\
\hline
\end{tabular}

D. Acclimatization: A growing, rooted shoot can be removed from tissue culture and placed in soil. When this is done, the humidity must be gradually reduced over time because tissue-cultured plants are extremely susceptible to wilting. The acclimatization in vivo was achieved easily with high percentage of success $(86.95 \%)$ in iris aurantica (Figure 6). Two months, later, plantlets were cultured in greenhouse and the average length of shoots were $23.25 \mathrm{~cm}$ [10].

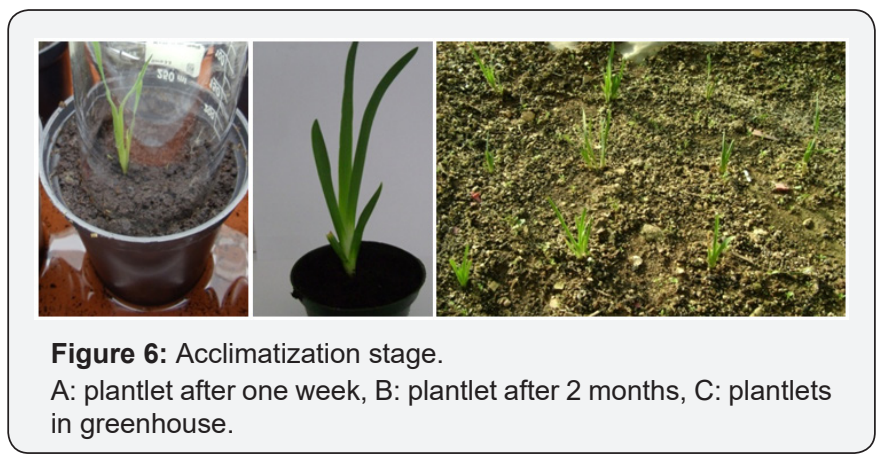

\section{In Vitro Conservation}

Conservation is a very simple in vitro technique that permits conservation plants material for periods ranging from 6 months to 5-7 years, depending on species [11]. This technique is based on reducing the growth rates of the tissue cultured plant and yet increasing the intervals between subcultures [12]. Research was conducted, to develop an in vitro technique for short-term conservation and relieve of growth and increase the period of time between transfers of Iris aurantica, The best osmotic agents for in vitro conservation was sucrose compared with (mannitol and sorbitol) and the best medium concentration was $1 / 10$ MS [10] in iris aurantica the cultured stored at $\left(3{ }^{\circ} \mathrm{C}\right)$ gave the highest survival $(93.33 \%)$ and lengthening the time period between transfers up to 6 months [10]. ABA was found to regulate expression of many genes that are responsible for the syntheses of proteins needed for osmotic adjustment in the cell, such as, membrane stabilization proteins, and the LEA proteins that would modify water state in the cell to cope with osmotic stress [13]. Some researchers reported that ABA is responsible for low temperature tolerance capacity of plant tissues [14]. In our research Iris aurantica micro shoots were conserved for more than nine months at normal growth room conditions in the media supplemented with 0.5 to $3.0 \mathrm{mg} / \mathrm{lABA}$, also ABA significantly decreases growth of shoots in medium when compared with control.

Results showed that the best survival after three, six and nine month were obtained in media supplemented with 2 and $3 \mathrm{mg} / \mathrm{l} \mathrm{ABA}$ with significant difference compared to the control at $3{ }^{\circ} \mathrm{C}$ and normal growth room conditions. The best treatments on germ plasm conservation were in $3 \mathrm{mg} / \mathrm{l} \mathrm{ABA}$ at $3{ }^{\circ} \mathrm{C}$, in these treatments the survival rate was $60 \%$.

\section{Long - Term Conservation (Cryopreservation)}

The principle of cryopreservation is the storage of plant material at ultra low temperature $\left(-196^{\circ} \mathrm{C}\right)$ that takes a place in a cryogenic condition which is liquid nitrogen [15]. At this 
temperature, all forms of cellular divisions and metabolic activities of plant cell are ceased and consequently plant material can be stored unaltered for an indefinite time scale $[16,17]$. Two techniques of cryopreservation were used in the case of Golden iris:

\section{VITRIFICATION}

Vitrification is based on three major phases, the loading phase, dehydration with the highly concentrated vitrification solutions, and unloading phase [18]. In loading phase samples are exposed to cryo protectants or diluted vitrification solutions [19] the samples are dehydrated by a highly concentrated vitrification solution before being plugged in LN, [20]. In unloading phase vitrification solution is drained out of the cryovials after rapid thawing, and then replaced routinely with 1.2 M sucrose for 10-20 min [21]. Plant vitrification solution 2 (PVS2) is commonly used in most vitrification protocols [22].

In our research Shoot-tips in Iris aurantica were excised aseptically from in vitro grown plants and incubated for 3 days on solid (HF-MS) media supplemented with $0.3 \mathrm{M}$ sucrose under complete darkness at $24 \pm 1^{\circ} \mathrm{C}$.in vitrification, shoot-tips were loaded in $0.4 \mathrm{M}$ sucrose and $2 \mathrm{M}$ glycerol for 20 min followed by desiccation with different combinations and concentrations of PVS2, before immersion in LN. Results showed that Subjecting $I$. aurantica shoot-tips to gradual increase in PVS2 concentrations $(20,40,60$, and $100 \%)$ before plunging them in LN gave the highest survival for the non-cryo preserved shoot-tips (50\%), and cryo preserved shoot-tips ( $30 \%$ ), respectively, Using of 2 $\mathrm{M}$ glycerol plus $0.4 \mathrm{M}$ sucrose resulted in the highest survival $(80 \%, 25 \%)$ for the non cryo preserved and cryo preserved Iris aurantia shoot-tips, respectively, The highest survival for the non cryo preserved I. aurantica shoot-tips was recorded after 30 min of loading.

\section{Encapsulation-Dehydration}

This method, developed [23] in which shoot tips, somatic embryos or callus cells are encapsulated within alginate beads and subsequent culture in a medium containing elevated concentrations $(0.7-1.5 \mathrm{M})$ of sucrose for 1 to 3 days [24,25]. The beads are then allowed to dehydrate using silica gel or by air under the laminar air flow until the moisture content drops to 20-30\% before being immersed in LN [23].

In our study shoot-tips in Iris aurantica were encapsulated in $3 \%$ calcium alginate and dehydrated under laminar air flow cabinet for $0,2,4$, or $6 \mathrm{~h}$. the highest survival were obtained after pre-treating encapsulated non-cryo preserved shoot-tips for 3 days in $0.5 \mathrm{M}$ sucrose supplemented media with $4 \mathrm{~h}$ dehydration.

\section{Chemical Analysis}

The medicinal parts of Iris (orris) species are the rhizomes with the roots. They contain volatile oil ( $\alpha, \beta, \gamma$, irons) giving the odor of violets triterpenes, isoflavonoids, flavonoids, xanthones and starch [26]. Some of Iris species were reported for their medical use. The isolated compounds from some species were demonstrated to have pesticide, anti neo plastic and anti tuberculosis properties [27]. The extract of I. germanica was found to have central anti serotonin activity [28].

Gas chromatography-mass spectrometry (GC-MS) analyses of the essential oil have indicated the presence of 23 compounds in Iris germanica, and 19 in Iris aurantica [29]. The major compound in these essential oils was Myristic acid (61.42\%, $70.67 \%$ ) in Iris germanica, and Iris aurantica respectively with no significant differences [29]. The findings here agreed with those obtained [30] which noted that the myristic acid was the major compound of the oil of the fresh and naturally aged rhizomes in Iris pallida which has antifungal properties [31]. The other sub major compounds obtained were Lauric acid, Decanoic acid (Capric acid), Palmitic acid methyl ester, Octadecanoic acid methyl ester, Elaidic acid methyl ester (9- Octadecenoic acid methyl ester (E) and Palmitic acid [29].

The highest percentage of Lauric acid was obtained (6.97\%) in I. aurantica, with no significant differences comparing with Iris germanica (5.69\%), these findings give us the possibility to investigate the use of iris aurantica for medical purposes [29].

\section{Iris Cultivation}

Wild Iris aurantica is very difficult to cultivate. It can withstand the cold and the heat as long as it is dry. Golden iris needs well drained soil and at least 6-8 hours sunlight. If the soils are heavy, sand or humus may be added to improve drainage. The ideal $\mathrm{pH}$ is less than 7 , slightly acidic. Iris should be planted in September or October, when the weather starts to cool, it is preferably to be divided and planted at least six weeks before the first frost in any area.

The rhizomes produce more rhizomes, which in turn lead to more leaves and flowers. One rhizome of golden iris can give more than ten flowers. When the bloom production slows and it is necessity to divide the plants, removing and replanting the baby rhizomes in spacing $15-25 \mathrm{~cm}$. Close planting results in immediate effect, faster clump formation, and makes dividing clumps a necessity in two to three years. New plantations of irises need moisture and fertilizer to help their root systems becomes established. Watering depends on the soil quality and the climatic conditions (Figure 7). It is preferable to give deep watering at long interval is better than shallow watering.

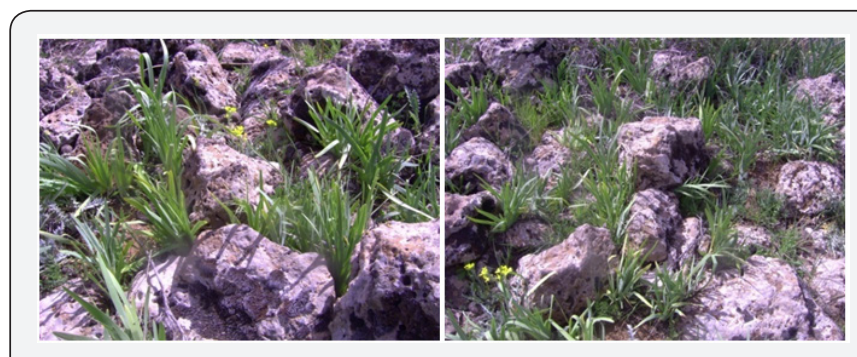

Figure 7: Soil of Mayamas AI Suwayda Syria. 


\section{References}

1. Moutrde P (1966) Nouvelle flore du Liban et de la Syrie. Del, Impri Catholique Beyrouth, Liban.

2. Trease WC (2002) Trease and Evan Pharmacognosy. W B Saunders, Edinburgh, London, New York, USA, pp. 26.

3. Rasoul TN (1984) Ornamental bulbs. Al-Mousel University, Iraq.

4. Dykes WR (1997) A Guide to Species Irises: Their Identification and Cultivation, edited by the Species Group of the British Iris society. Cambridge University, pp. 424.

5. Werckmeister P (1963) The Iris aurantica of Syria. Bulletin of the American Iris society. 169: 29-30.

6. Al Maarri K (2016) Final report of project wild Iris in Syria: study of genetic variability, propagation, conservation, active compound and biological effect. High commission scientific research, pp. 115.

7. Mathew B (1989) The Iris. Oregon Timber Press, Portland, Oreg, pp. 326 .

8. Jehan H, Courtois D, Ehret C, Lerch K, Petiar V (1994) Plant regeneration of Iris pallid Lam and Iris germanica L via somatic embryogenesis from leaves, apices and young flowers. Plant Cell Rep 13(12): 671- 675.

9. Abouzedan T, AlBatal N, Al Maarri K (2012) In vitro micro propagation and chemical analysis of some wild Iris species in Syria. Master of Faculty of Agriculture, Damascus University, 99 pages.

10. Abouzedan T, AlBatal N (2016) In vitro Micro propagation and Conservation of Iris aurantica L in Syria. The Arab Center for the Studies of Arid Zones and Dry lands (ACSAD).

11. El-Dawayati MM, Zaid ZE, Elsharabasy SF (2012) Effect of Conservation on Steroids Contents of Callus Explants of Date Palm cv. Sakkoti Aust J Basi Appl Sci 6(5): 305-310.

12. Engelmann F (1991) In vitro conservation of tropical plant germplasm - a review. Euphytica 57(3): 227-243.

13. Taiz L, Zeiger E (2002) Plant Physiology. 3rd edn, Sinauer Associates Pubilsher, Hardcover.

14. Popova EV, Lee EJ, Wu CH, Hahn EJ ,Paek KY (2009) A simple method for cryopreservation of Ginkgo bilobacallus. Plant Cell Tiss Org Cult 97(3): 337-343.

15. Wen B, Wang RL (2010) Pretreatment incubation for culture and cryo preservation of Sabal embryos. Plant Cell Tissue Organ Cult 102: 237 243.

16. Gonzalez-Arnao MT, William AP, Roca R, Escobar RH, Engelmann F (2008) Development and large scale application of cryopreservation techniques for shoot and somatic embryo cultures of tropical crops. Plant Cell Tissue Organ Cult 92(1): 1-13.
17. Shatnawi MA, Anfoka G, Shibli RA, Al-Mazra'awi MS, Shahrour W, et al. (2011) Clonal Propagation and cryogenic storage of virus free grapevines (Vitis vinefera L.) via meristem culture. Turk J Agric For 35: $173-184$.

18. Ashmore SE (1997) Status report on the development and application of in vitro techniques for the conservation and use of plant genetic resources. Rome.

19. Withers LA (1991) In vitro conservation. Biol J linn Soc 43: 31-42.

20. Sakai A, Kobayashi S, Oiyama I (1991) Survival by vitrification of nucellar cells of navel orange (Citrus sinensisvar. brasiliensis Tanaka) cooled to $-196^{\circ} \mathrm{C}$. J Plant Physiol 137: 465-470.

21. Shibli RA, Shatnawi M, Subaih W, Ajlouni M (2006) In vitro conservation and cryopreservation of plant genetic resources: A review. World J Agric Sci 2: 372-382.

22. Reed BM (2008) Plant cryopreservation: A practical guide. USDA-ARS National Clonal Germplasm Repository. Corvallis, USA, 3(11): 33-41.

23. Fabre J, Dereuddre J (1990) Encapsulation-dehydration: a new approach to cryopreservation of Solanum shoot tips. Cryo Letters 11: 413-426.

24. Gonzalez-Arnao MT, Engelmann F (2006) Cryopreservation of plant germ plasm using the encapsulation-dehydration technique: Review and case study on sugarcane. Cryo Letters 27(3):155-168.

25. Shatnawi MA, Engelmann F, Frattarelli A, Damiano C (1999) Cryopreservation of apices of in vitro plantlets of almond (Prunusdulcis Mill.). Cryo Letters 20(1): 13-20.

26. Guvence A, Kurucu S, Koyuncu M, Arihan O, Erdurak CS (2005) Investigation on the seeds of Iris spuria L Subsp musulmanica (fomin) takht (Iridaceae). Turkish J Pharm Sci 2(3): 125-136.

27. Deng G, Zhang H, Xue H, Chen SH, Chen X (2009) Chemical composition and biological activities of essential oil from the rhizomes of Iris bulleyana. Agric Sci China 8(6): 691-696.

28. Al Maarri K, Abouzedan T, AlBatal N (2013) Chemical analysis of essential oils of some syrian wild Iris species. Am J Biochem Mol Biol 3(1): 38-49.

29. Deng G, Zhang X, Wang T, LinY, Chen X (2008) Chemical composition and antimicrobial activity of the essential oil of Iris pallid Lam. Chem Industry Forest Prod 28(3): 39-44.

30. Parang K, Knaus EE, Wiebe LL, SardariS, Daneshtalab M, et al. (1996) Synthesis and antifungal activities of myristic acid analogs. Chem Life Sci 329(11): 475-482.

31. Bonfils JP, Pinguet F, Culine S, Sauvaire Y (2001) Cytotoxicity of iridals, triterpenoids from Iris, on human tumor cell lines A2780 and K562. Planta Med 67(1): 79-81.
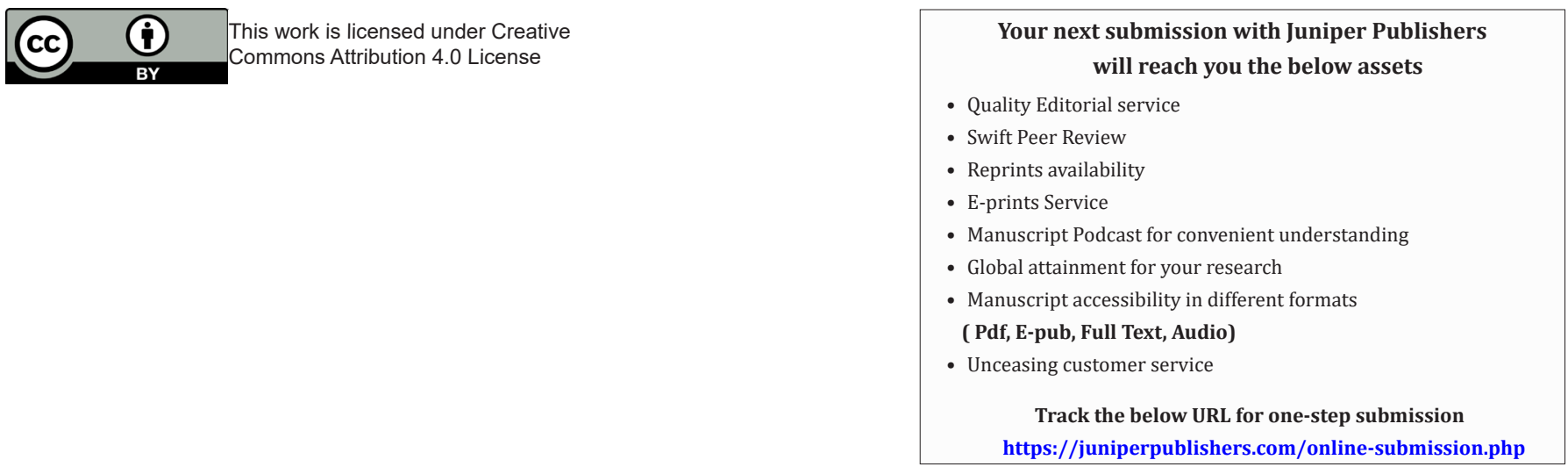